\title{
Effect of Mini-Sprinkler Irrigation on Yield of Two Hybrid Maize Varieties under Two Levels of Fertilization on Dryland of Nangakara Area, Sumbawa, Indonesia
}

\author{
Wayan Wangiyana $^{1 *}$, I Gusti Made Kusnarta ${ }^{2}$
}

\begin{abstract}
${ }^{1}$ Department of Agronomy, Faculty of Agriculture, University of Mataram, Mataram, Lombok, Indonesia ${ }^{2}$ Department of Soil Science, Faculty of Agriculture, University of Mataram, Mataram, Lombok, Indonesia *Corresponding author
\end{abstract}

\begin{abstract}
With the construction of a dam and its irrigation canals in the irrigation area of Nangakara River, in Pekat district of Dompu regency in West Nusa Tenggara Province (NTB), Indonesia, it was necessary to carry out an irrigation water management test farm, for use as a basis for making recommendations and as a demonstration area for the farmers. This study aimed to examine the effect of two different irrigation techniques, between sprinkler (LSI) and surface (CSI) irrigation, and two fertilization packages, on yield of two hybrid maize varieties on dryland with sandy soils. The experiment was organized according to Split Split-Plot design with three blocks and three treatment factors, namely hybrid maize varieties (Bisi-2 and C-7) as main plot, irrigation techniques (LSI and CSI) as sub-plots, and fertilizer doses ( F1= low level; F2= moderate level) as sub-sub-plots. The results indicated that there were no significant interaction effects among treatment factors, but there were significant effects of both irrigation techniques and levels of fertilizer doses on all observation variables, except for the weight of 1000 dry grains. In general, both the higher level of fertilizer doses (F2) and application of sprinkler irrigation (LSI) resulted in higher dry grain yield, water use efficiency (WUE), weights of harvested ears and harvested stover. However, the C-7 variety showed higher response to fertilizer doses especially under sprinkler irrigation. On average, grain yield was significantly higher under sprinkler (12.54 ton/ha) than surface irrigation (10.17 ton/ha), indicating the disadvantages of surface versus sprinkler irrigation. The harvested stover weight was higher on Bisi-2 (21.19 ton/ha) than on C-7 (13.98 ton/ha), but the dry grain yield tended to be higher on $C-7(12.0 \mathrm{t} / \mathrm{ha})$ than on Bisi-2 (10.7 t/ha), indicating that $\mathrm{C}-7$ was higher in the rate of assimilate partitioning into seeds than the Bisi-2 variety.
\end{abstract}

Keywords - Hybrid maize, Bisi-2, C-7, sprinkler irrigation, fertilizer doses.

\section{INTRODUCTION}

Maize or corn (Zea mays L.) is one of the multifunctional food crops, because all of the above-ground parts of the plants can be economically utilized. There are a variety of uses of maize, including for food, feed and fuel, and for use as raw materials for food industries [1]. Maize grains consist of different parts, i.e. endosperm, germ, pericarp and tip cap, and for food or food industries, whole maize grains contain $68-74 \%$ starch, $8-11 \%$ protein and $4.0-5.5 \%$ fat, while the endosperm contains $85 \%$ starch, $8.5 \%$ protein, and relatively low $(1 \%)$ fat [2]. However, the proximate composition of maize grains, especially in the endosperm depends on the types of maize crop; there are quality protein maize (QPM), sweet corn, waxy maize, and other specialty maize having different composition of the endosperm compared with the normal yellow dent maize [3].

As a food crop, maize is a globally important cereal crop, and its position is third after wheat and rice [4]. In Indonesia, based on the total harvested area (https://bps.go.id/subject/53/tanaman-

pangan.html\#subjekViewTab3), maize is the second most important food crop after rice, which in 2015 the total harvested area of maize was $3,787,367$ ha while that of rice 
was $14,116,638$ ha. In spite of this, the total domestic production of maize in Indonesia was still unable to meet the total domestic need for it, so Indonesia still imports maize from several countries. According to Haryono [1], although the domestic production has increased significantly, maize trade in Indonesia shows a negative trend since 1999, due to the increasing domestic demand for feed and food industries. Therefore, maize production has to be increased by increasing the productivity and/or the areas for growing maize crop. However, maize cultivation in irrigated lands is only possible during the dry seasons following harvest of rainy-season or dry-seasonone ("MK1") rice crop because of the high demand for irrigated lands for growing rice instead of growing non-rice crops. Therefore, increasing maize growing areas can only be done by extending its growing areas to the available dryland areas.

One of the main obstacles for productive cultivation of maize crop on drylands is the unavailability of irrigation water during the dry seasons, especially in the dry land areas with rainy seasons of up to or less than 3-4 wet months. In these types of dryland areas, the use of water, either from the rains or wells, for irrigating food crops has to be kept highly efficient. One of the district area of $943.22 \mathrm{~km}^{2}$ which dominated by dryland areas is "Pekat" district in "Dompu" regency of the West Nusa Tenggara (NTB) Province in Indonesia. The dryland area in this district is dominated by sandy soils with a short rainy season of only 4 wet months or less. According to the Statistics of Pekat district (https://docplayer.info/66772346-Statistik-daerah-

kecamatan-pekat-2015.html), the wet months in this district area are normally started in December followed by January, February and March only, and the other months of the year are normally dry months with mostly no rain.

With the construction of a dam on the Nangakara River in "Pekat" district in 2007 , there is an opportunity to extend the production of food crops such as maize and other annual food crops beyond the rainy seasons in this area. However, the main purposes of the construction of this Nangakara Dam was to provide water for a source of clean water for the population and for providing supplementary irrigation in the production of secondary food crops, but not for growing rice. If it is used for production of irrigated rice, the discharge is insufficient, so the residents were discouraged the government to grow irrigated rice. In order to manage the use of water efficiently, before finishing the construction of the dam and the irrigation canals, it was necessary to carry out water management tests (test farm) for various types of non-rice crops, for use as a basis for making recommendations (farm guidance) on management of water use from the Nangakara dam, and as the demonstration area of water management in various non-rice food crops. The Test Farm was carried out in three cropping seasons, in which the third cropping season was in the form of mini-farm project, consisting of six mini-farms of 0.50 ha each with different crops.

This paper aimed to report the results obtained from two mini-farms to examine the effect of two different irrigation techniques, i.e. between limited sprinkler irrigation (LSI) and conventional surface irrigation (CSI) techniques, and two fertilization packages, on yield of two varieties of hybrid maize crops, i.e. "Bisi-2" and "C-7" varieties.

\section{MATERIALS AND METHOD}

In this study an experimental method was used by carrying out field experiments during the dry season 1 (MK1) of 2007 in the third cropping season of the mini farm test in the irrigation area of the Nangakara River, in Pekat district of Dompu regency in West Nusa Tenggara (NTB) Province, Indonesia. The experiment was designed according to Split Split Plot (SSP) design with three blocks (replications) and three treatment factors, namely hybrid maize varieties $(\mathrm{V} 1=$ Bisi-2; V2= C-7) as the main plot factor, irrigation techniques, consisting of two treatments $(\mathrm{I} 1=$ LSI (limited sprinkler irrigation); $\mathrm{I} 2=\mathrm{CSI}$ (conventional surface irrigation)) as sub-plot factor, and fertilizer packages (P1 and P2) as the sub-sub-plot factor.

The conventional surface irrigation (CSI) was done by mimicking the way the farmers irrigate their land, namely by flooding the land with surface irrigation, while limited sprinkler irrigation (LSI) was done using a mini sprinkler, with a radius of water sprays as far as $3 \mathrm{~m}$ from the sprinkler's head, making an artifical rain water with a diameter of $6 \mathrm{~m}$. The installation of the pipe line was carried out by PT Bahagia Bangunnusa of Dompu Regency, as the company working on the construction of the Nangakara Dam and its irrigation channels. In each mini-farm, two main taps were installed with water meters, each for the CSI and LSI techniques. After calibration and measurement of water use, it was found that the amount of water applied to the LSI was an average of $400 \mathrm{~L} /$ are/day (or $40,000 \mathrm{~L} / \mathrm{ha} /$ day) while for CSI it was an average of $600 \mathrm{~L} / \mathrm{are} /$ day (or 60,000 L/ha/day). The fertilizer application treatments consisted of two levels of doses, i.e. a low dose (P1), which consisted of $150 \mathrm{~kg} / \mathrm{ha}$ Urea $(45 \%$ $\mathrm{N}), 100 \mathrm{~kg} / \mathrm{ha} \mathrm{SP}-36\left(36 \% \mathrm{P}_{2} \mathrm{O}_{5}\right)$, and 5 ton/ha cattle manure, and a medium dose (P2), which consisted of 250 $\mathrm{kg} / \mathrm{ha}$ Urea, $150 \mathrm{~kg} / \mathrm{ha} \mathrm{SP}-36$ and 5 ton/ha cattle manure. 
The experiment was started with soil tillage, starting in May 2007, followed by establishment of mini-farm plots and treatment plots on each mini-farm, as well as installation of water distribution pipes. The hybrid maize varieties (Bisi-2 and C-7) were planted by dibbling the seeds with a planting distance of $40 \mathrm{~cm}$ in rows and $75 \mathrm{~cm}$ between rows, by allowing two plants to grow per planting hole. The manure was applied at the entire dose at the time of planting by placing it at the bottom of the planting hole, which was then covered with a thin soil layer, and the seeds were placed on it, and it was then covered with soil. The entire dose of SP-36 fertilizer mixed with one third of Urea fertilizer was applied by dibbling them beside the maize plants at 7 days after planting (DAP), and the remaining dose of Urea fertilizer was applied at 35 DAP by dibbling the fertilizer followed by soil piling. An evaporation pan and a rainfall gauge were also installed in the test-farm location. When there was no rain, watering was done every two days for LSI and four days for CSI, especially since the end of the vegetative growth stages of the maize plants.

The measured plant data included the weight of the harvested cobs, harvested stover weight, dry grain yield, which were measured from 10 clumps of sample plants per treatment plot, which were then converted to ton/ha, as well as the weight of 1000 dry grains and water use efficiency (WUE). The WUE was calculated using dry grain yield per ha divided by total $\mathrm{mm}$ of irrigation water used by the maize plants, based on the formula from Kirda [5], so that the unit of WUE is $\mathrm{kg} / \mathrm{ha} / \mathrm{mm}$. Data were analyzed with Analysis of Variance (ANOVA) and the Tukey's HSD test at 5\% level of significance, using the statistical software CoStat for Windows ver. 6,303. The graphs are displayed using the Mean and Standard Error (SE) values, using the method from Riley [6].

\section{RESULTS AND DISCUSSION}

The results of preliminary soil analysis of the representative soil samples taken before running the experiment indicated that soil in the test farm site was relatively fertile, with an average value: $\mathrm{pH}$ 6.47; concentration of $\mathrm{Ca}, \mathrm{Mg}, \mathrm{K}, \mathrm{Na}$ and $\mathrm{CEC}$ respectively $6.02 ; 2.52 ; 1.76 ; 0.47$ and $18.30 \mathrm{me} / 100 \mathrm{~g}$ of air-dried soil; organic C $1.85 \%$, total $\mathrm{N} 0.14 \%$, available $\mathrm{P}$ (Bray-1) $11.50 \mathrm{mg} / \mathrm{kg}$, with a texture of $79.0 \%$ sand, $16.5 \%$ dust and $4.5 \%$ clay. Therefore, the soil is classified as sandy soil, with the main constraint was unavailability of water, and water was only available during the rainy seasons.

Based on the ANOVA results summarized in Table 1, it can be seen that there was no significant interaction effects among the three treatment factors tested. However, the irrigation techniques and fertilization packages had a significant effect on all measurement variables, except for the weight of 1000 dry grains, while the varieties of hybrid maize only showed significant differences in harvested stover weight.

Based on the results of the Tukey's HSD test at 5\% level of significance (Table 2), it can be seen that the average weight of the harvested cobs, harvested stover weight, water use efficiency (WUE) and dry grain yield per ha, are all higher in the P2 fertilizer doses compared with in the $\mathrm{P} 1$ doses, where in the $\mathrm{P} 2$ doses, the average dry grain yield was 12.02 ton/ha compared with 10.69 ton/ha in the $\mathrm{P} 1$ doses. This indicates that the hybrid maize plants were still responsive to increasing the fertilizer doses from a low dose (P1) to a moderate dose (P2). However, this level of productivity was still lower than the potential yield of these hybrid maize varieties listed in their description, which was 10-12 ton/ha dry grains for C7 and 13 ton/ha for Bisi-2 variety. These indicate that the doses of fertilizers for these hybrid maize varieties at the test farm location can still be increased in order to achieve a higher level of productivity, especially the dose of manure application, considering that the soil is classified as sandy soil.

Similarly, the technique of watering the crops needs to be improved. If water is available, farmers usually provide water through surface irrigation, by flooding the land, which in this study was referred to as CSI treatment (irrigation by farmers' techniques). When compared with the limited sprinkler irrigation technique (LSI), which in its application was carried out using a mini sprinkler, it appears from Table 2 that the LSI technique with a sprinkler was significantly superior when compared to the CSI technique (the farmers' techniques), where the average dry grain yield per ha was higher in LSI (12.54 ton/ha), compared with in CSI (10.17 ton/ha).

The higher average productivity of the hybrid maize in the LSI treatment compared with in the CSI treatment was most probably due to differences in the process or rate of nutrient mobilization in the soil between the two irrigation techniques. The land where the test farm was carried out was classified as sandy soil, so that surface irrigation by flooding the land in the CSI technique was thought to cause leaching of nutrients, both for those available in the soil and those provided through fertilizer application. Lv et al. [7], who tested the distribution of $\mathrm{N}$ and $\mathrm{P}$ nutrients, as well as the growth and yield of maize planted after wheat as a result of irrigation techniques applied to wheat plants, showed that the main zone of nutrient absorption is closer to the surface of the land on those irrigated with sprinkler irrigation techniques, when compared with the land that 
was irrigated with surface irrigation, which decreases the amount of available $\mathrm{N}$ and $\mathrm{P}$. Moreover, if the land is dominated by sandy soils, surface irrigation will provide a greater chance of infiltration compared with sprinkler irrigation, thereby also causing greater nutrient leaching in surface irrigation techniques (CSI) compared with limited droplet irrigation techniques using sprinklers (LSI).

In relation to the amount of irrigation water applied, Al-Kaisi and Yin [8] also showed that the maize plants reached the highest WUE in water supply of $0.80 \mathrm{ET}$ compared to $1.00 \mathrm{ET}$ and $0.60 \mathrm{ET}$, mainly because maize grain yields were even higher in water supply of $0.80 \mathrm{ET}$ compared with water supply of 1.00 ET and 0.60 ET. This researchers were also concerned about the presence of nutrient leaching, especially nitrates, in the presence of a higher fertilizer doses and water supply, so that the grain yield is not significantly different between the water supply of $0.80 \mathrm{ET}$ (total water supply $510 \mathrm{~mm}$ ) compared with $1.00 \mathrm{ET}$ (total water supply of $640 \mathrm{~mm}$ ). Even from their results of experiments in 1999, the average yield of maize kernels was higher in water supply of 0.80 ET compared with water supply of $1.00 \mathrm{ET}$, which was 12.47 versus
$12.29 \mathrm{ton} / \mathrm{ha}$ at a fertilizer dose of $140 \mathrm{~kg} / \mathrm{ha} \mathrm{N}$, and 13.49 versus $13.30 \mathrm{ton} / \mathrm{ha}$ at a fertilizer dose of $250 \mathrm{~kg} / \mathrm{ha} \mathrm{N}$ [8].

Looking at the differences in the average dry grain yield between the two hybrid maize varieties, Bisi-2 and C7, differences appear to be non-significant (Table 1), but there was a tendency that the grain yield was higher in the C-7 variety (12.00 ton/ha) than in Bisi-2 variety (10.71 ton/ha) (Table 2). However, the weight of harvested stover and the weight of harvested cobs tended to be higher in Bisi-2 than in C-7 variety. This means that the rate of assimilate partition to seeds was higher in C-7 than in Bisi2 variety. In addition, if the percentage of dry grain yield is calculated against the weights of harvested cobs and harvested stover, the values are higher in C-7 $(82.87 \%$ and $85.84 \%$, respectively) than in Bisi-2 variety $(60.78 \%$ and $50.54 \%$, respectively), which also indicates that the rates of assimilate partition to seeds are higher in C-7 than in Bisi-2 variety. Bisi-2 is a maize variety that always produces two cobs per plant, while C-7 produces only one cob per plant. Producing two cobs in Bisi-2 variety would require more assimilates to be deposited in the inner part of the cob, which at the end results in more wastes of naked cobs in the Bisi-2 compared with in the C-7 variety.

Table 1. Summary of ANOVA results of the effect irrigation techniques and fertilizer packages on weights of harvested cobs, harvested stover, 1000 dry grains, dry grain yield, and water use efficiency of two hybrid maize varieties

\begin{tabular}{lccccc}
\hline Source of variation & $\begin{array}{c}\text { Harvest cob } \\
\text { weight }\end{array}$ & $\begin{array}{c}\text { Harvest stover } \\
\text { weight }\end{array}$ & $\begin{array}{c}\text { Weight of 1000 dry } \\
\text { grains }\end{array}$ & $\begin{array}{c}\text { Dry grain } \\
\text { yield }\end{array}$ & WUE \\
\hline Blocks & $\mathrm{ns}$ & $\mathrm{ns}$ & $\mathrm{ns}$ & $\mathrm{ns}$ & $\mathrm{ns}$ \\
Variety (V) & $\mathrm{ns}$ & $*$ & $\mathrm{~ns}$ & $\mathrm{~ns}$ & $* * *$ \\
Irrigation (I) & $*$ & $*$ & $\mathrm{~ns}$ & $\mathrm{~ns}$ & $*$ \\
I*V interaction & $\mathrm{ns}$ & $\mathrm{ns}$ & $\mathrm{ns}$ & $\mathrm{ns}$ & $\mathrm{ns}$ \\
Fertilizer (F) & $* *$ & $*$ & $\mathrm{~ns}$ & $\mathrm{~ns}$ & $\mathrm{~ns}$ \\
F*V interaction & $\mathrm{ns}$ & $\mathrm{ns}$ & $\mathrm{ns}$ & $\mathrm{ns}$ \\
F*I interaction & $\mathrm{ns}$ & $\mathrm{ns}$ & $\mathrm{ns}$ & $\mathrm{ns}$ \\
F*I*V interaction & $\mathrm{ns}$ & $\mathrm{ns}$ & &
\end{tabular}

Remarks: $\quad \mathrm{ns}=$ non-significant $(p$-value $>=0.05), * * *, * * *=$ significant at $p$-value $<0.05 ;<0.01 ;<0.001$, respectively.

Tabel 2. Average weights of harvested cobs (t/ha), harvested stover ( $t / h a)$, 1000 dry grains, dry grain yield ( $t /$ ha), and WUE $(\mathrm{kg} / \mathrm{ha} / \mathrm{mm})$ for each level of treatment factors, and their Tukey's HSD values at $5 \%$ level of significance

\begin{tabular}{ccccccc}
\hline Treatments & $\begin{array}{c}\text { Harvest cob } \\
\text { weight (t/ha) }\end{array}$ & $\begin{array}{c}\text { Harvest stover } \\
\text { weight (t/ha) }\end{array}$ & $\begin{array}{c}\text { Weight of 1000 dry } \\
\text { grains (g) }\end{array}$ & $\begin{array}{c}\text { Dry grain yield } \\
(\mathbf{t} / \mathbf{h a})\end{array}$ & WUE (kg/ha/mm) \\
\hline Fertilizer package: & & & & & & \\
F1 & $15.02 \mathrm{~b}$ & $16.13 \mathrm{~b}$ & $300.09 \mathrm{a}$ & $10.69 \mathrm{~b}$ & $25.30 \mathrm{~b}^{1)}$ \\
F2 & $17.09 \mathrm{a}$ & $19.04 \mathrm{a}$ & $300.01 \mathrm{a}$ & $12.02 \mathrm{a}$ & $28.37 \mathrm{a}$
\end{tabular}




\begin{tabular}{|c|c|c|c|c|c|}
\hline HSD 0.05 & 1.23 & 2.38 & 17.08 & 0.84 & 2.13 \\
\hline \multicolumn{6}{|c|}{ Irrigation types: } \\
\hline LSI & $17.82 \mathrm{a}$ & $18.91 \mathrm{a}$ & $301.43 \mathrm{a}$ & $12.54 \mathrm{a}$ & $34.83 \mathrm{a}$ \\
\hline CSI & $14.28 \mathrm{~b}$ & $16.26 \mathrm{~b}$ & $298.68 \mathrm{a}$ & $10.17 \mathrm{~b}$ & $18.83 \mathrm{~b}$ \\
\hline HSD 0.05 & 2.83 & 2.37 & 11.10 & 1.75 & 3.87 \\
\hline \multicolumn{6}{|c|}{ Maize hybrids: } \\
\hline Bisi-2 & $17.62 \mathrm{a}$ & $21.19 \mathrm{a}$ & $298.25 \mathrm{a}$ & $10.71 \mathrm{a}$ & $25.50 \mathrm{a}$ \\
\hline C-7 & $14.48 \mathrm{a}$ & $13.98 \mathrm{~b}$ & $301.85 \mathrm{a}$ & $12.00 \mathrm{a}$ & $28.16 \mathrm{a}$ \\
\hline HSD 0.05 & 3.53 & 3.46 & 6.82 & 2.71 & 4.94 \\
\hline
\end{tabular}

\footnotetext{
1) Mean values in each column of a variable followed by the same letters are not significantly different between levels of a treatment factor (main effects)
}

The appearance of the plants in the field also different, where the C-7 plants appeared to be on average greener than the Bisi-2 maize plants, at the same level of fertilizer doses (Figure 1), indicating higher nitrogen content of the leaves in C-7 than in Bisi-2 variety. According to Sinclair and de Wit [9], the rate of seed filling in seed plants is largely determined by nitrogen supply, both from absorption by roots and from the results of remobilization of nitrogen from the leaves to the growing seeds if the rates of $\mathrm{N}$-uptake by the roots are inadequate to meet $\mathrm{N}$ requirements of the developing seeds. From Figure 2, it can also be seen that the hybrid maize variety " $\mathrm{C}-7$ " was more responsive to increasing the fertilizer doses because the difference in dry grain yield between the F2 and F1 doses were significant in C-7 variety but it was non-significant in Bisi-2 variety, both under the LSI and CSI irrigation techniques.
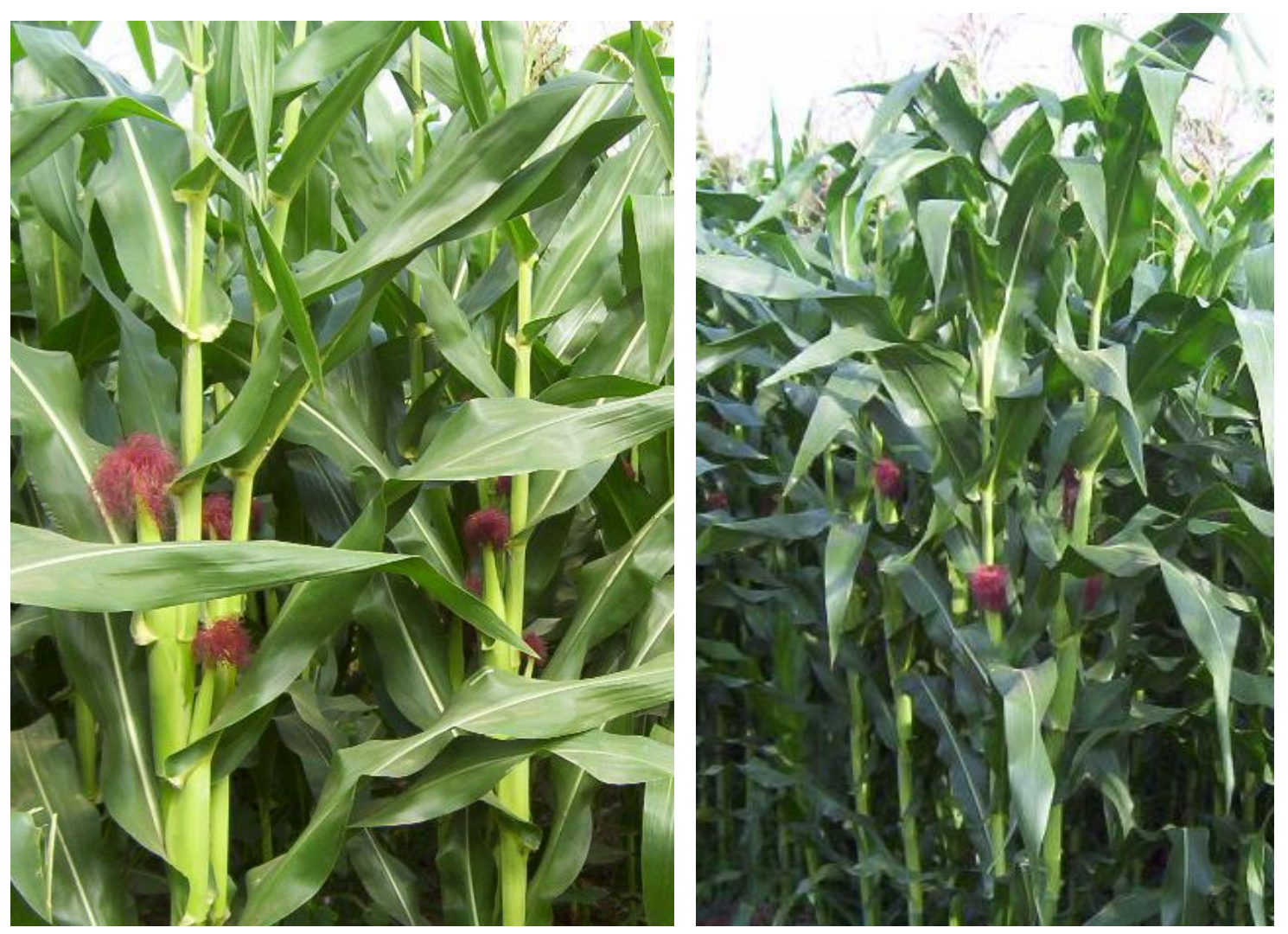

Fig.1: Growth performance of Bisi-2 (LEFT) and C-7 (RIGHT) after silking, in which C-7 plants showed greener leaves than Bisi-2 plants 


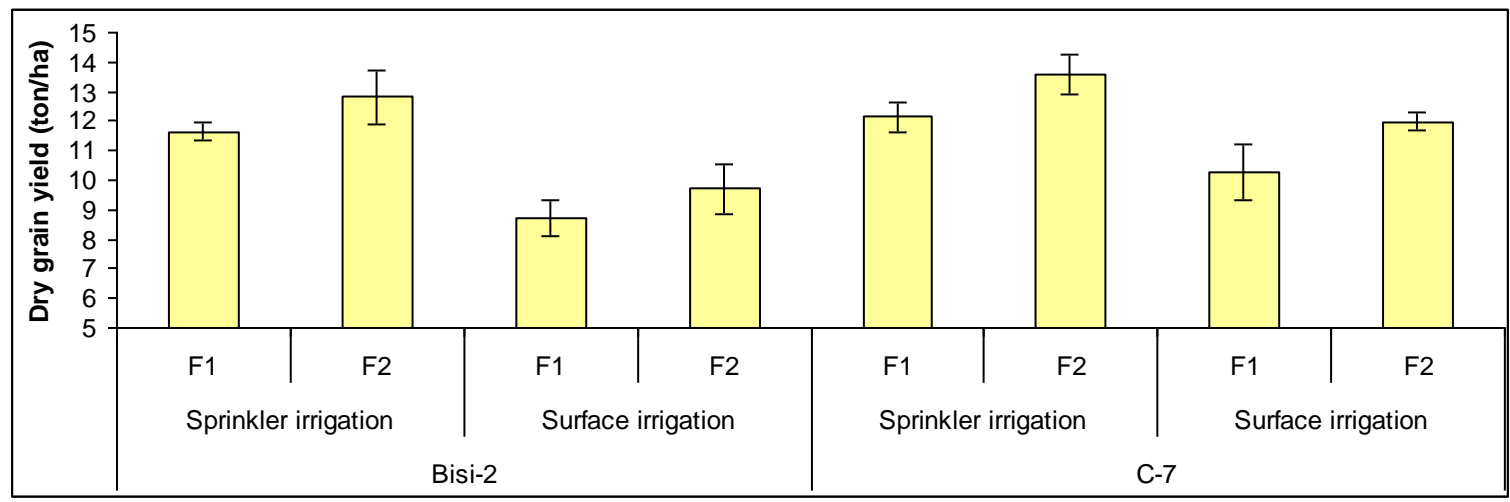

Fig.2: Graphs of averages (Mean \pm SE) of dry grain yield (ton/ha) of maize plants for each treatment combination of irrigation techniques (LSI vs CSI) and fertilizer doses (F1 vs F2) between hybrid maize varieties (Bisi-2 vs C-7)

\section{CONCLUSION}

It can be concluded that maize dry grain yield was significantly lower under surface irrigation technique than under sprinkler irrigation technique, indicating more disadvantages of surface irrigation than sprinkler irrigation technique for irrigating maize crops on dryland with sandy soils either under low or moderate doses of fertilizer packages.

\section{ACKNOWLEDGEMENTS}

Through this article the authors express special thanks to the PT Bahagia Bangunnusa for funding the test farm and for providing all the facilities needed to run the test farm, from which parts of the data were taken for preparing this article.

\section{REFERENCES}

[1] Haryono. 2013. Maize for Food, Feed and Fuel in Indonesia: Challenges and Opportunity. Pp. 3-9. Proceedings of International Seminar on Agribusiness of Maize-Livestock Integration. Agency for Agricultural Research and Development, Jakarta, Indonesia.

[2] Singh, N., Kaur, A., and Shevkani, K. 2014. Maize: Grain Structure, Composition, Milling, and Starch Characteristics. In: D.P. Chaudhary, S. Kumar, S. Langyan (Eds), Maize: Nutrition Dynamics and Novel Uses. Pp. 6576. Springer India 2014. DOI: 10.1007/978-81-322-1623$0 \_5$.

[3] Hallauer, A.R. 2001. Specialty Corns. $2^{\text {nd }}$ Edition. CRC Press LLC, Boca Raton, Florida, USA.

[4] Chaudhary, D.P., Kumar, S., and Yadav, O.P. 2014. Nutritive Value of Maize: Improvements, Applications and Constraints. In: D.P. Chaudhary, S. Kumar, S. Langyan (Eds), Maize: Nutrition Dynamics and Novel Uses. Pp. 317. Springer India 2014. DOI: 10.1007/978-81-322-16230_1.
[5] Kirda, C. 2002. Deficit irrigation scheduling based on plant growth stages showing water stress tolerance. pp. 3-10. In: Deficit Irrigation Practices. FAO Water Report. FAO, Rome.

[6] Riley, J. 2001. Presentation of statistical analyses. Experimental Agriculture, 37: 115-123.

[7] Lv, G., Kang, Y., Li, L., and Liu, S. 2011. Nutrient Distribution, Growth, and Water Use Efficiency in Maize Following Winter Wheat Irrigated by Sprinklers or Surface Irrigation. Irrigation and Drainage, 60: 338-347.

[8] Al-Kaisi, M.M., and Yin, X. 2003. Effects of Nitrogen Rate, Irrigation Rate, and Plant Population on Corn Yield and Water Use Efficiency. Agronomy J., 95: 1475-1482.

[9] Sinclair, T.R., and de Wit, C.T. 1975. Photosynthate and nitrogen requirements for seed production by various crops. Science, 189: 565-567. 